\title{
ANALISIS JENIS DAN KADAR SAPONIN EKSTRAK AKAR KUNING (Fibraurea chloroleuca Miers) SECARA GRAVIMETRI
}

\section{Analysis Of The Types And Levels Of Akar Kuning (Fibraurea chloroleuca Miers) Extract By Gravimetric}

\author{
Wira Darma, Mauritz Pandapotan Marpaung \\ Universitas Kader Bangsa, Palembang \\ email: mauritzchem@gmail.com
}

\begin{abstract}
Abstrak. Akar kuning (Fibraurea chloroleuca Miers) merupakan salah satu tanaman yang mempunyai banyak manfaat dalam pengobatan dengan kandungan metabolit sekunder berupa alkaloid, flavonoid, saponin, tanin, steroid dan terpenoid. Tujuan penelitian ini untuk mengetahui jenis dan kadar saponin ekstrak akar kuning. Proses ekstraksi telah dilakukan melalui metode refluks dengan pelarut metanol. Analisis jenis saponin menggunakan pereaksi LB (LiebermannBurchard) dan kadarnya ditentukan dengan metode gravimetri. Hasil penelitian menunjukkan jenis saponin ekstrak akar kuning adalah saponin triterpenoid

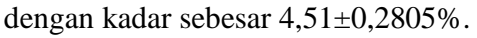

Kata kunci: Akar kuning, saponin, gravimetri.

\begin{abstract}
Akar kuning (Fibraurea chloroleuca Miers) is one of the plants that has many benefits in the treatment with secondary metabolites such as alkaloids, flavonoids, saponins, tannins, steroids and terpenoids. This study is aimed to determine the types and levels of saponin on the akar kuning extract. The extraction process has been done by reflux method with methanol solvent. Analysis of saponin types using LB (Liebermann-Burchard) reagent and yields was determined by the gravimetric method. The results showed that the type of saponin from akar kuning extract was triterpenoid saponin with its levels of $4.506 \pm 0.2805 \%$.
\end{abstract}

Keywords: Akar kuning, saponin, gravimetric.

\section{PENDAHULUAN}

Saponin merupakan salah satu senyawa metabolit sekunder dalam tumbuhan yang ditandai busa stabil ketika dilarutkan dan digojog dalam air (Harbone, 1996). Senyawa ini merupakan jenis glikosida yang mengandung molekul gula dengan 2 (dua) jenis aglikon yaitu steroid (C-27) dan triterpenoid (C-30). Jika saponin steroid dan triterpenoid dihidrolisis masing-masing akan menghasilkan saraponin dan sapogenin (Hanani, 2015). Peranan saponin steroid secara farmakologi adalah dapat mengobati penyakit reumatik, anemia, diabetes, syphilis, impotensi, dan antifungi sedangkan 
saponin triterpen berperan sebagai antibakteri, antijamur, antiinflamasi dan ekspetoran (Evans, 2002).

Untuk menganalisis kadar saponin dalam tumbuhan dapat dilakukan berbagai metode seperti TLC Scanner, Spektrofotometri UV-Vis, Kromatografi Cair Kinerja Tinggi (KCKT) dan metode gravimetri (Minarno, 2016; Mien dkk, 2015). Pada penelitian ini menggunakan metode gravimetri karena sangat sederhana dalam pengerjaannya yang didasarkan pada penimbangan berat konstan dari suatu senyawa setelah melakukan pelarutan sampel, penambahan pereaksi, penyaringan, pencucian, pengeringan dan penimbangan endapan hingga konstan (Pursitasari, 2014).

Pada penelitian sebelumnya, telah dilakukan identifikasi jenis dan kadar saponin dari beberapa ekstrak bahan alam. Pada ekstrak metanol daun kemangi (Ocimum basilicum L.) memiliki kandungan jenis saponin steroid dengan kadar rata-rata sebesar $3,11 \pm 0,00795 \%$ melalui metode gravimetri (Marpaung \& Romelan, 2018). Lain hanya pada ekstrak etanol bunga senggani (Melastoma malabathricum L.) mengandung saponin jenis triterpenoid dengan kadar rata-rata adalah $11,46 \%$ melalui metode yang sama yaitu gravimetri (Noviyanty dkk, 2020). Sedangkan pada ekstrak daun Inggu (Ruta angustifolia L.) mengandung kadar saponin rata-rata yaitu 2,13\% dengan menggunakan metode TLC Scanner (Noer dkk, 2018). Untuk ekstrak daun lidah mertua (Sansevieria trifasciata Prain varietas S. Laurentii) mengandung kadar rata-rata saponin dengan metode gravimetri sebesar 3,1258\% (Mien dkk, 2015). Dengan menggunakan metode spektrofotmetri UV-Vis, kandungan saponin dalam daun dan tangkai daun karika (Carica pubescens Lenne \& K. Koch) dari kawasan Cangar yang didasarkan pada nilai absorbansi masing-masing yaitu 0,686 dan 0,852 dengan jenis saponin yang sama yaitu saponin triterpenoid (Minarno, 2016).

Berdasarkan beberapa hasil penelitian tersebut, setiap ekstrak bahan alam menujukkan kandungan jenis dan kadar rata-rata saponin yang berbeda-beda. Tumbuhan yang mengandung saponin dapat ditemukan pada tumbuhan berbunga. Beberapa suku tumbuhan berbunga yang mengandung saponin steroid adalah Liliaceae, Amaryllidaceae, dan Dioscoreaceae. Sedangkan suku tumbuhan yang mengandung saponin triterpen adalah Meliaceae, Cucurbitaceae, dan Simarubaceae (Hanani, 2015).

Salah satu tumbuhan berbunga dengan suku Menispermaceae adalah akar kuning (Fibraurea chloroleuca Miers). Akar kuning merupakan tumbuhan liana (merambat) yang menumpang pada pohon-pohon lain hingga mencapai $40 \mathrm{~m}$ (Samah et al., 2013). Masyarakat Dayak di Kalimantan menggunakan tumbuhan ini sebagai obat sakit perut, obat tetes mata, sakit kuning, sariawan, cacingan dan sebagai plester pada penyakit cacar oleh masyarakat Ambon (Balitbang Palangkaraya, 2018). Selain itu, akar kuning juga telah dilaporkan mempunyai aktivitas antioksidan yang kuat dan efek diuretik yang telah diuji dengan tikus putih jantan galur Wistar (Marpaung \& Handayani, 2018; Marpaung dkk, 2017).

Banyaknya manfaat yang terdapat pada akar kuning perlu dilakukan standardisasi untuk menjadikan akar kuning sebagai salah satu tanaman obat yang berkhasiat. Salah satu langkah melakukan standardisasi suatu tanaman adalah menentukan kadar metabolit sekunder yang terdapat di dalamnya. Akar kuning sendiri mengandung senyawa metabolit sekunder berupa flavonoid, alkaloid, saponin, dan tanin (Marpaung dkk, 2017). Kadar metabolit sekunder akar kuning yang telah ditentukan adalah flavonoid 
sebesar 0,31031 $\pm 0,0136 \%$ (Marpaung \& Wahyuni, 2018). Sampai dilakukan penelitian ini, belum dilaporkan jenis dan kadar saponin pada akar kuning.

Tujuan dari penelitian ini adalah untuk mengetahui jenis dan kadar saponin yang terdapat pada akar kuning. Dengan diketahui jenis dan kadar saponin pada akar kuning, diharapkan dapat diketahui efek farmakologi lain terhadap peranan saponin dalam kesehatan.

\section{METODE PENELITIAN}

Alat

Alat-alat yang digunakan dalam penelitian ini adalah batang pengaduk, blender, corong (Pyrex), corong pisah, erlenmeyer (Pyrex), gelas piala (Iwaki Pyrex), gelas ukur (Pyrex), kain kasa, kertas saring Whatman, labu alas bulat, neraca analitik (Ohaus), oven, pipet, rotary evaporator (Dragonlab RE100 Pro), tabung reaksi, waterbath (APin Samcheung), dan seperangkat alat refluks.

\section{Bahan}

Bahan-bahan yang digunakan dalam penelitian ini adalah akar kuning yang diperoleh dari Desa Sengir, Kecamatan Payung, Kabupaten Bangka Selatan, Kepulauan Bangka Belitung. Metanol (Indo Reagen), akuades, dietil eter (Merck), etil asetat (Kimia ARD), $\mathrm{HCl}$, klorofom (Merck), n-butanol (Kimia ARD), petroleum eter (Kimia ARD), dan pereaksi LB (Liebermann-Burchard).

\section{Determinasi akar kuning}

Untuk menentukan nama atau jenis secara spesifik dari tanaman yang diteliti dilakukan determinasi tanaman. Determinasi dilakukan dengan mengirimkan sampel tanaman akar kuning ke Laboratorium Herbarium Biologi, Fakultas MIPA, Universitas Andalas, Padang.

\section{Pembuatan ekstrak kental akar kuning}

Akar kuning dicuci dan dikeringkan secara tidak langsung di bawah sinar matahari serta dihaluskan untuk mendapatkan simplisia. Sebanyak 50 gram simplisia direfluks dengan metanol selama 30 menit pada suhu $50-60^{\circ} \mathrm{C}$. Ekstrak metanol diuapkan dengan rotary evaporator pada suhu $50^{\circ} \mathrm{C}$. Kemudian ditimbang dan dihitung persentase rendemen (Marpaung \& Romelan, 2018). Perhitungan persentase rendemen dapat dilakukan dengan menggunakan rumus berikut (Wijaya dkk, 2018):

$$
\text { Rendemen }=\frac{\text { Bobot ekstrak kental (g) }}{\text { Bobot simplisia (g) }} \times 100 \%
$$

\section{Identifikasi saponin}

Sebanyak 0,5 g akar kuning dilarutkan dalam $10 \mathrm{ml}$ air panas. Kemudian didinginkan dan dikocok kuat selama 10 detik. Kemudian ditambahkan 1 tetes $\mathrm{HCl} 2 \mathrm{~N}$ melalui dinding tabung reaksi Terbentuk buih yang stabil selama tidak kurang dari 10 menit menunjukkan adanya saponin dalam sampel (Marjoni, 2016). 


\section{Identifikasi jenis saponin}

Sebanyak $0,5 \mathrm{~g}$ simplisia dimasukkan ke dalam $10 \mathrm{ml}$ kloroform dan dipanaskan selama 5 menit dengan penangas air sambil dikocok. Kemudian ditambahkan beberapa tetes pereaksi LB (Liebermann-Burchard). Jika terbentuk cincin coklat atau violet maka menunjukkan adanya saponin triterpenoid, sedangkan warna hijau atau biru menunjukkan adanya saponin steroid (Suharto dkk, 2012).

\section{Analisis kadar saponin secara gravimetri}

Sebanyak 1 gram ekstrak direfluks dengan $50 \mathrm{~mL}$ petroleum eter pada suhu 60$80^{\circ} \mathrm{C}$ selama 30 menit. Setelah dingin larutan petroleum eter dibuang dan residu yang tertinggal dilarutkan dalam $50 \mathrm{~mL}$ etil asetat. Larutan dipindahkan ke corong pisah kemudian dipisahkan larutan etil asetat. Residu yang tertinggal dilarutkan dengan nbutanol sebanyak 3 (tiga) kali masing-masing dengan $50 \mathrm{~mL}$.

Seluruh larutan tersebut dicampur dan diuapkan dengan rotary evaporator dengan suhu $60-70^{\circ} \mathrm{C}$. Sisa penguapan dilarutkan dengan metanol $10 \mathrm{ml}$ kemudian larutan ini diteteskan ke dalam $50 \mathrm{~mL}$ dietil eter sambil diaduk. Endapan yang terbentuk dalam campuran dituang pada kertas saring yang telah diketahui bobotnya. Kertas saring dikeringkan kemudian ditimbang sampai bobot tetap. Selisih bobot kertas saring sebelum dan sesudah penyaringan ditetapkan sebagai bobot saponin dilakukan sebanyak 3 (tiga) kali dengan hasil perhitungan kadar rata-ratanya dan dibuat pada tabel (Marpaung \& Romelan, 2018).

\section{Analisis data}

Analisis data dilakukan secara univariat dimana kadar saponin yang dihitung dengan menggunakan rumus di bawah ini.

$$
\text { Kadar Saponin }=\frac{\mathrm{X} 2-\mathrm{X} 1}{\mathrm{~A}} \times 100 \%
$$

Keterangan:

$\mathrm{X} 1$ : bobot kertas saring $(\mathrm{g})$

$\mathrm{X} 2$ : bobot kertas saring + endapan saponin $(\mathrm{g})$,

A : bobot ekstrak akar kuning $(\mathrm{g})$

\section{HASIL PENELITIAN DAN PEMBAHASAN}

Untuk mengetahui kebenaran identitas tanaman yang akan diteliti perlu dilakukan determinasi tumbuhan. Determinasi tumbuhan akar kuning yang dilakukan di Laboratorium Herbarium, Universitas Andalas, Padang menunjukkan jenis Fibraurea chloroleuca Miers dengan famili Menispermaceae.

Kemudian dilakukan ekstraksi dengan menggunakan metode refluks di dalam pelarut metanol. Refluks merupakan salah satu metode ekstraksi yang menggunakan alat kondensor melalui proses pemanasan selama waktu dan jumlah pelarut tertentu. Metode ini digunakan karena merupakan proses ekstraksi yang cukup sempurna. Hal ini disebabkan karena refluks dilakukan 3-5 kali pengulangan pada residu pertama (Marjoni, 2016). Penggunaan pelarut metanol dalam ekstraksi karena metanol merupakan senyawa organik bersifat polar yang sangat baik untuk melarutkan saponin. Pelarut yang paling tepat digunakan dalam ekstraksi untuk melarutkan saponin adalah metanol dan etanol 
dengan konsentrasi 70\% sampai dengan 95\% (Harbone, 1996). Dari hasil ekstraksi melalui metode cara panas yaitu refluks diperoleh persentase rendemen dengan karakteristik ekstrak kental akar kuning yang terdapat pada Tabel 1.

Tabel 1. Rendemen dan karakteristik ekstrak akar kuning

\begin{tabular}{cccccc}
\hline \multirow{2}{*}{$\begin{array}{c}\text { Bobot } \\
\text { simplisia }\end{array}$} & $\begin{array}{c}\text { Bobot ekstrak } \\
\text { kental }\end{array}$ & Rendemen & Bentuk & Warna & Bau \\
\cline { 4 - 6 } & $3,465 \mathrm{~g}$ & $6,93 \%$ & Kental & Coklat & Khas \\
\hline
\end{tabular}

Pada Tabel 1 menunjukkan hasil ekstraksi akar kuning dengan rendemen sebesar $6,93 \%$. Rendemen merupakan persentase hasil ekstraksi yang diperoleh dari hasil bagi bobot ekstrak kental terhadap bobot simplisia. Semakin kecil persentase suatu rendemen maka semakin baik hasil ekstraksi yang diperoleh. Pada Tabel 1 juga menunjukkan hasil karakteristik akar kuning dengan bentuk yang kental, berwarna coklat dan memberi bau yang khas.

Sebelum menentukan kadar saponin pada akar kuning dilakukan identifikasi saponin dengan menggunakan pereaksi asam klorida $(\mathrm{HCl})$. Adanya saponin dalam ekstrak ditandai dengan terbentuknya busa stabil seperti pada Gambar 1. Busa yang timbul pada ekstrak menunjukkan adanya glikosida yang memiliki kemampuan membentuk busa dalam air yang terhidrolisis menjadi senyawa glukosa dan aglikon (Mien dkk, 2015). Pembentukan busa pada ekstrak menunjukkan saponin merupakan senyawa makromolekul yang mempunyai sifat yang dapat menurunkan tegangan permukaan air. Hal ini disebabkan karena saponin memiliki dua (2) gugus yaitu gugus hidrofilik yang merupakan gugus yang larut zat yang bersifat polar seperti air dan gugus lipofilik yang merupakan gugus yang larut dalam zat yang bersifat nonpolar seperti lemak/minyak. Dengan adanya penyerapan molekul saponin dalam permukaan air mnenyebabkan terjadinya penurunan tegangan permukaan air yang mengakibatkan terbentuknya busa.

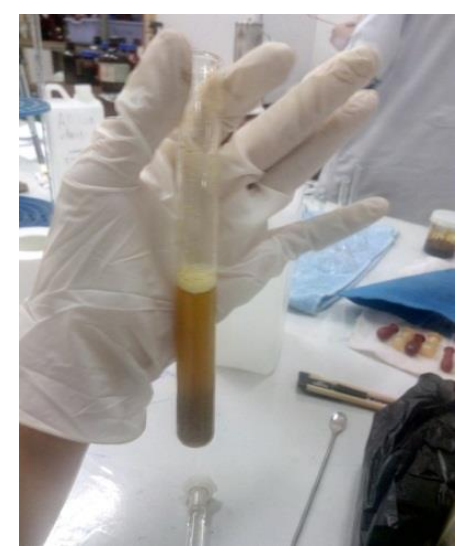

Gambar 1. Pembentukan busa stabil pada akar kuning dari identifikasi saponin. 
Dalam penentuan jenis saponin pada Gambar 2 menunjukkan akar kuning mengandung jenis saponin-triterpeneoid yang ditandai dengan cincin berwarna coklat. Untuk menentukan jenis saponin pada ekstrak akar kuning menggunakan pereaksi LB (Liebermann-Burchard). Pereaksi LB merupakan campuran antara asam asetat anhidrida dengan asam sulfat pekat yang digunakan untuk reaksi warna dalam mengidentifikasi jenis saponin dalam suatu simplisia.

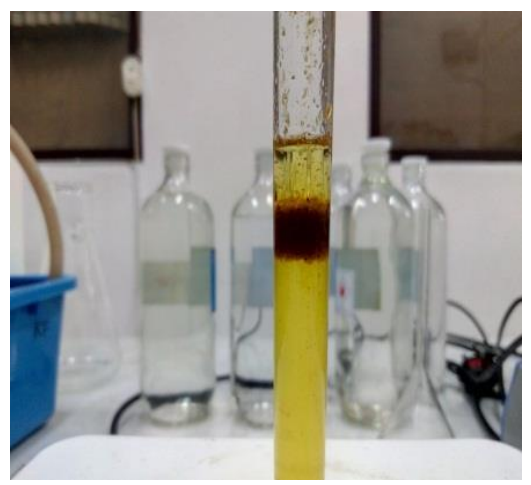

Gambar 2. Pembentukan cincin coklat yang menandakan jenis saponin triterpenoid

Saponin triterpenoid merupakan senyawa yang bersifat asam, berbentuk kristal, tidak berwarna, titik lebur yang tinggi, mengandung oksigen, memiliki 1 sampai 6 molekul monosakarida, dan mengandung beberapa senyawa asam alifatik dalam bentuk ester. Sifat asam pada saponin ditandai adanya satu atau dua gugus -CO-- (karbonil) dalam aglikon atau molekul gula. Adanya kandungan oksigen pada saponin kemungkinan mengandung gugus hidroksil $(-\mathrm{OH})$, aldehida $(-\mathrm{CHO})$, atau $-\mathrm{CH}_{2} \mathrm{OH}$. Jenis saponin ini memiliki aktivitas hemolitik dengan kekuatan yang berbeda tergantung pada jenis atau tipe substitusinya (Hanani, 2015).

Kadar rata-rata saponin yang diperoleh dari ekstrak akar kuning dalam tiga perlakuan melalui analisis gravimetri yang disajikan pada Tabel 2 adalah $4,51 \pm 0,2805 \%$. Penggunaan metode gravimetri dilakukan karena tidak dibutuhkan zat pembanding dalam menentukan kadar saponin. Metode gravimetri merupakan salah satu metode analisis kuantitatif untuk menentukan bobot zat murni dan stabil yang telah diketahui setelah melalui proses isolasi dalam suatu campuran.

Tabel 2. Kadar saponin ekstrak akar kuning secara gravimetri

\begin{tabular}{ccccc}
\hline \multirow{2}{*}{ Perlakuan } & X2 & X1 & A & $\begin{array}{c}\text { Kadar Saponin } \\
(\mathbf{\%})\end{array}$ \\
\hline I & $1,2662 \mathrm{~g}$ & $1,2175 \mathrm{~g}$ & $1,0159 \mathrm{~g}$ & 4,79 \\
II & $1,2927 \mathrm{~g}$ & $1,2469 \mathrm{~g}$ & $1,0141 \mathrm{~g}$ & 4,51 \\
III & $1,2254 \mathrm{~g}$ & $1,1827 \mathrm{~g}$ & $1,0096 \mathrm{~g}$ & 4,22 \\
& \multicolumn{3}{c}{ Rata-rata } \\
\multicolumn{3}{c}{ Standar Deviasi (SD) } \\
\hline
\end{tabular}

Proses yang terjadi pada penentuan kadar saponin pada ekstrak akar kuning secara gravimetri adalah proses pengendapan. Dalam proses pengendapan, kandungan 
saponin dalam ekstrak akar kuning diendapkan dari larutannya dalam bentuk senyawa yang sukar larut sehingga dalam penyaringan, pencucian dan penimbangan tidak ada senyawa yang hilang. Kemurnian endapan tergantung pada bahan-bahan yang ada dalam larutan sebelum dan sesudah penambahan reagen dan kondisi pengendapan (Gandjar \& Rahman, 2007). Metode gravimetri memiliki beberapa kelebihan diantaranya adalah tingkat sensitifitas yang tinggi, hasil analisis data pengukuran yang spesifik dan tepat, mudah dalam pengoperasiannya, dan dapat mengetahui pengotor yang terdapat dapat sampel.

Dari hasil presentase kadar saponin pada ekstrak akar kuning maka dapat diketahui kemungkinan khasiat yang terdapat dalam tanaman akar kuning. Saponin mempunyai khasiat terhadap tanaman itu sendiri dan pencegahan atau pengobatan dari suatu penyakit. Bagi tanaman, khususnya jenis saponin triterpenoid bermanfaat sebagai pertahanan alami yang dapat mengancam keberlangsungan kehidupan tanaman dari serangan hama serangga, jamur ataupun bakteri. Pada serangga, saponin membentuk kompleks tidak larut dengan kolesterol yang merupakan sumber energi utama bagi serangga. Hal ini menyebabkan kolesterol yang berikatan dengan saponin tidak dapat digunakan sehingga terjadi kematian pada serangga. Pada bakteri, saponin membentuk kompleks reversibel di dalam dinding sel sehingga mengakibatkan rusaknya membran sel (Di Fabio et al., 2014).

Pada pencegahan atau pengobatan penyakit, saponin berperan sebagai antibakteri, antifungi, antivirus, pengontrol kadar glukosa darah, serta mampu menghambat pertumbuhan sel tumor (Yanuartono dkk, 2017). Berdasarkan hasil penelitian terhadap daging mahkota dewa (Phaleria macrocarpa) dengan kadar rata-rata saponin yaitu $20,4 \%$ dapat mencegah terjadinya penyakit diabetes dengan menghambat kerja enzim $\alpha$-glukosidase dalam memproduksi glukosa dari karbohidrat. Dengan demikian, saponin dapat menimbulkan efek hipoglikemia yaitu terjadi penurunan kadar glukosa dalam darah (Fiana \& Oktaria, 2016). Sedangkan pada kulit batang tumbuhan kasturi (Mangifera casturi) dengan fraksi saponin mempunyai aktivitas sebagai antibakteri terhadap Escherichia coli dan Staphylococcus aureus dengan diameter hambat masing-masing sebesar 10,3 $\pm 0,5 \mathrm{~mm}$ dan $10,8 \pm 0,3 \mathrm{~mm}$. Terjadinya difusi pada saponin melalui membran luar dan dinding sel dengan mengikat membran sitoplasma menyebabkan terganggunya kestabilan membran sel. Hal ini membuat terjadinya kebocoran pada sitoplasma yang mengakibatkan kematian sel bakteri (Rosyidah dkk, 2010). Ekstrak Anabasis articulata yang mengandung saponin juga mempunyai aktivitas antibakteri terhadap Escherichia coli ATCC 25922, Staphylococcus aureus ATCC 6538, Klebsiella pneumonia, Bacillus subtilis ATCC 6633, Pseudomnas aureginosa ATCC 14028 dan antijamur terhadap Candida albicans dengan rentang konsentrasi hambat minimum (KHM) yaitu 0,5 sampai $1 \mathrm{mg} / \mathrm{ml}$ (Maatalah et al., 2012). Mekanisme kerja saponin sebagai antijamur adalah dengan sifatnya menghasilkan buih dapat menurunkan tegangan permukaan membran sterol dari dinding sel jamur sehingga permeabilitas membran meningkat. Hal ini mengakibatkan enzim, protein, dan nutrisi di dalam sel keluar sehingga terjadi kematian pada jamur (Dewi dkk, 2019).

Peranan jenis saponin triterpenoid dalam pencegahan dan pengobatan adalah sebagai ekspektoran yaitu merangsang pengeluaran dahak dari saluran pernapasan. Selain itu, jenis saponin ini juga mempunyai aktivitas sebagai antiinflamasi (mengurangi 
peradangan) dan larvasida (membunuh jentik nyamuk di tempat penampungan air) (Noviyanty dkk, 2020).

\section{SIMPULAN}

Dari hasil penelitian yang telah dilakukan maka jenis saponin yang terdapat dalam ekstrak akar kuning (Fibraurea chloroleuca Miers) adalah saponin triterpenoid dengan kadar rata-rata $4,51 \pm 0,2805 \%$.

\section{DAFTAR RUJUKAN}

Balitbang Palangkaraya. (2018). Khasiat Akar Kuning Kalimantan Untuk Kesehatan. https://balitbangkota.palangkaraya.go.id/khasiat-akar-kuning-kalimantan-untukkesehatan/

Dewi, S., Asseggaf, S. N., Natalia, D., \& Mahyarudin, M. (2019). Efek Ekstrak Etanol Daun Kesum (Polygonum minus Huds.) sebagai Antifungi terhadap Trichophyton rubrum. Jurnal Kesehatan Andalas, 8(2), 198-203. https://doi.org/10.25077/jka.v8i2.992

Di Fabio, G., Romanucci, V., De Marco, A., \& Zarrelli, A. (2014). Triterpenoids from Gymnema sylvestre and their pharmacological activities. Molecules, 19(8). https://doi.org/10.3390/molecules 190810956

Evans, W. C. (2002). Trease and Evans Pharmacognosy. 15th edtion. Edinburgh, Saunders.

Fiana, N., \& Oktaria, D. (2016). Pengaruh Kandungan Saponin dalam Daging Buah Mahkota Dewa (Phaleria macrocarpa) terhadap Penurunan Kadar Glukosa Darah. Jurnal Majority, 5(4), 128-132.

Gandjar, I. G., \& Rahman, A. (2007). Kimia Farmasi Analisis (Sudjadi (ed.)). Pustaka Pelajar.

Hanani, E. (2015). Analisis Fitokimia. Penerbit Buku Kedokteran EGC.

Harbone, J. B. (1996). Metode Fitokimia: Penuntun cara modern menganalisis tumbuhan. ITB.

Maatalah, M. B., Bouzidi, N. K., Bellahouel, S., Merah, B., Fortas, Z., Soulimani, R., Saidi, S., \& Derdour, A. (2012). Antimicrobial activity of the alkaloids and saponin extracts of Anabasis articulata. E3 Journal of Biotechnology and Pharmaceutical Research, 3(3), 54-57.

Marjoni, M. R. (2016). Dasar-dasar fitokimia untuk diploma III farmasi. Trans Info Media.

Marpaung, M. P., \& Handayani, D. W. (2018). The effect of solvent concentration on antioxidant activity of akar kuning (Fibraurea chloroleuca Miers) extract. AIP Conference Proceedings, 2049 (December). https://doi.org/10.1063/1.5082504

Marpaung, M. P., Mardiansah, Y., \& Wulandari, W. (2017). Aktivitas Diuretik Dan Skrining Fitokimia Ekstrak Etanol Akar Kuning (Fibraurea chloroleuca Miers) Pada Tikus Putih Jantan Galur Wistar. Prosiding Seminar Nasional POKJANAS TOI Ke 52, April, 277-285. https://sites.google.com/stifarriau.ac.id/pokjanastoistifar2017/prosiding

Marpaung, M. P., \& Romelan, R. (2018). ANALISIS JENIS DAN KADAR SAPONIN EKSTRAK METANOL DAUN KEMANGI (Ocimum basilicum L.) DENGAN MENGGUNAKAN METODE GRAVIMETRI. JFL: Jurnal Farmasi Lampung, 
7(2), 81-86. https://doi.org/10.37090/jfl.v7i2.57

Marpaung, M. P., \& Wahyuni, R. C. (2018). Identifikasi Dan Penetapan Kadar Flavonoid Total Ekstrak Akar Kuning (Fibraurea chloroleuca Miers). Talenta Conference Series: Tropical Medicine (TM), 95-98. https://doi.org/10.32734/tm.v1i3.269

Mien, D. J., Carolin, W. A., \& Firhani, P. A. (2015). Penetapan kadar saponin pada ekstrak daun lidah mertua. Jurnal Ilmu Dan Teknologi Kesehatan, 2(2), 65-69.

Minarno, E. B. (2016). ANALISIS KANDUNGAN SAPONIN PADA DAUN DAN TANGKAI DAUN Carica pubescens Lenne \& K. Koch. El-Hayah, 5(4), 143-152. https://doi.org/10.18860/elha.v5i4.3470

Noer, S., Pratiwi, R. D., \& Gresinta, E. (2018). Penetapan Kadar Senyawa Fitokimia (Tanin, Saponin dan Flavonoid) sebagai Kuersetin Pada Ekstrak Daun Inggu (Ruta $\begin{array}{lllll}\text { angustifolia } & \text { L.). Jurnal Eksakta, 18(1), }\end{array}$ https://doi.org/10.20885/eksakta.vol18.iss1.art3

Noviyanty, Y., Hepiyansori, \& Dewi, B. R. (2020). IDENTIFIKASI DAN PENETAPAN KADAR SENYAWA SAPONIN EKSTRAK ETANOL BUNGA SENGGANI (Melastoma malabathricum L) METODE GRAVIMETRI. Oceana Biomedicina Journal, 3(1), 45-53.

Pursitasari, I. D. (2014). Kimia Analitik Dasar dengan strategi problem solving dan Open Ended Experiment. Alfabeta.

Rosyidah, K., Nurmuhaimina, S. A., Komari, N., \& Astuti, M. D. (2010). AKTIVITAS ANTIBAKTERI FRAKSI SAPONIN DARI KULIT BATANG TUMBUHAN KASTURI (Mangifera casturi). ALCHEMY, 1(2), 65-69. https://doi.org/10.18860/al.v0i0.1674

Samah, A. R. M., Mustapha, Z. A., \& Hussein, N. (2013). ASEAN Herbal And Medicinal Plants. ASEAN Secretariat, Jakarta, Indonesia.

Suharto, M. A. P., Edy, H. J., \& Dumanauw, J. M. (2012). ISOLASI DAN IDENTIFIKASI SENYAWA SAPONIN DARI EKSTRAK METANOL BATANG PISANG AMBON(Musa paradisiaca var. sapientum L.). PHARMACON, 1(2), 86-92.

Wijaya, H., Novitasari, \& Jubaidah, S. (2018). Perbandingan Metode Ekstraksi Terhadap Rendemen Ekstrak Daun Rambut Laut (Sonneratia caseolaris L. Engl). Jurnal Ilmiah Manuntung, 4(1), 79-83.

Yanuartono, Purnamaningsih, H., Nururrozi, A., \& Indarjulianto, S. (2017). Saponin: Dampak terhadap Ternak (Ulasan). Jurnal Peternakan Sriwijaya, 6(2), 79-90. https://doi.org/10.33230/jps.6.2.2017.5083 